European Journal of Pragmatism and American Philosophy

$\mid-1 / 2$ | 2009

Europe and American Pragmatism: Influences and Interactions

\title{
Charles Peirce's First Visit to Europe, 1870-71
}

Scientific Cooperation and Artistic Creativity

Jaime Nubiola and Sara Barrena

\section{OpenEdition}

Electronic version

URL: http://journals.openedition.org/ejpap/970

DOI: 10.4000/ejpap.970

ISSN: 2036-4091

\section{Publisher}

Associazione Pragma

Electronic reference

Jaime Nubiola and Sara Barrena, «Charles Peirce's First Visit to Europe, 1870-71 », European Journal of Pragmatism and American Philosophy [Online], I-1/2 | 2009, Online since 01 July 2009, connection on 20 April 2019. URL : http://journals.openedition.org/ejpap/970 ; DOI : 10.4000/ejpap.970

This text was automatically generated on 20 April 2019.

\section{c) (†) $९$}

Author retains copyright and grants the European Journal of Pragmatism and American Philosophy right of first publication with the work simultaneously licensed under a Creative Commons AttributionNonCommercial-NoDerivatives 4.0 International License. 


\title{
Charles Peirce's First Visit to Europe, 1870-71 \\ Scientific Cooperation and Artistic Creativity
}

\author{
Jaime Nubiola and Sara Barrena
}

\section{AUTHOR'S NOTE}

We are very grateful to the editors of EJPAP for their kind invitation to take part in this inaugural issue. We are also very grateful to the "Programa de Investigación de la Universidad de Navarra" for the funding of the project developed by Sara Barrena, Hedy Boero, Izaskun Martínez, Marta Morgade, Jaime Nubiola, Paloma Pérez-Ilzarbe and Ignacio Redondo. The authors of the paper are in debt with all the members of the Group for their help, and particularly with Guy Debrock for editing the English version.

1 Charles S. Peirce has been commonly identified as the most original and versatile intellect that America has ever produced (Weiss, 1934: 403; Fisch 1981a: 17; etc.). He was not only a philosopher, but a true polymath. His reflections cover a wide range of disciplines. Peirce's thought combines a rich knowledge of the philosophical tradition and the history of science with his valuable personal experience as a logician and as an experimental researcher. His deep involvement in scientific activity over a period of several decades provided him with a genuine acquaintance with scientific practice that enabled him to develop a theoretical understanding of scientific creativity and of the real logic of discovery. Moreover, Peirce was also sensitive to the artistic dimension of creativity. Even though his theoretical remarks about Art are sketchy at best, he always remained fascinated by the phenomenon of art. In this respect, one ought to keep in mind that, as a youngster, he read and studied Friedrich Schiller's theory of art as expressed in his Aesthetische Briefe. But, as Peirce confesses in 1905: "As for esthetics, although the first year of my study of philosophy was devoted to this branch exclusively, yet I have since 
then so completely neglected it that I do not feel entitled to have any confident opinions about it" (CP 5.129, 1905).

Both elements-real interest in science and personal connection with art-which already appear in the early stages of Peirce's thought may in some sense be seen as a mirror of his experience of life. In this respect, the aim of the project entitled "Peirce's European Correspondence: Artistic Creativity and Scientific Cooperation," as developed by the Grupo de Estudios Peirceanos ${ }^{1}$ during the years 2007-09 and funded by the Plan of Research of the University of Navarra (PIUNA), is precisely to explore this in some detail. More specifically, the main goal of this project is to scrutinize Peirce's European letters, that is to say, the letters written during his five visits to Europe between June 1870 and September 1883, as well the correspondence that he maintained throughout his life with a good number of European scientists and intellectuals of his time. It is our firm conviction that a careful reading of these letters, - until now not easily accessible -, may change the common image of Charles S. Peirce as an isolated thinker, locked up in his house in Milford, PA. A clear understanding of his "cosmopolitan period" - to use Max Fisch's expression (1986: 227) - shows that Peirce was in several ways an European scientist and philosopher and-maybe unexpectedly-an above average expert in art.

So far, the research of the project that will stretch over several years to come, has focused on the 17 surviving letters of Peirce's first trip to Europe (June 1870-March 1871), and the letters addressed to eight of his European correspondents: Mario Calderoni, Augustus De Morgan, Hermann Helmholtz, Stanley Jevons, Edward H. Palmer, Ventura Reyes y Prósper, Victoria Lady Welby and Wilhelm Wundt.

4 This article gives an account of the research developed so far and of its main results. First, there is a description of the initial plan and of the context in which the research was framed. Secondly, several historical and biographical data of Peirce's first visit to Europe will be presented. Indeed, the inventory of these data constitutes the heart of the project. Thirdly, the results will be analyzed according to our main points of interest: 1) Peirce's conception of science and of the scientific community and 2) Peirce's view of artistic creativity. Moreover, there will be a brief summary of the results of his correspondence with the European scientists. Finally, the paper will conclude with a general summary of the achievements of the project.

\section{Outline and Description of the Project}

5 From its very beginning, several years ago, the Group of Peirce Studies as a team, has aimed at making an original and novel contribution to the study of the figure and thought of Charles S. Peirce. So far, our main contribution - including a good number of doctoral dissertations on C. S. Peirce and other pragmatists - has focused on the translations of Peirce's texts into Spanish and on the reception of Peirce in the Hispanic world (Nubiola \& Zalamea 2006). The extensive work over a number of years in this area has put our Group visibly on the map of international research concerning Peirce, particularly so in the Spanish-speaking countries.

Charles Peirce's abundant correspondence, most of which is preserved in the Houghton Library at Harvard University and is registered in Robin's catalogue, seemed to us an element of Peirce's immense written production that had been neglected by most of scholars. This neglect may be due largely to the difficult access to those letters. They were 
available exclusively at the Houghton Library, the Institute for Studies in Pragmaticism in Lubbock, Texas, and the Peirce Edition Project in Indianapolis. Within the project, the expression "European letters," which constitute but a small part of the thousands of letters written by Peirce, refers to those letters that were written by Peirce during his visits to Europe, as well as those he addressed to European scientists and intellectuals in the course of his life. The letters written from abroad provide a very valuable picture of Peirce's complex personality, his opinions regarding aesthetics, his artistic evaluations and also his concerns and anxieties, all of which complement in a significant way the philosophical standard approach to Peirce that has been developed by most of scholars who simply had no access to those letters. More specifically, we were deeply attracted by the letters that Peirce wrote to his wife Zina and to other members of his family during his first trip of 1870-71. The set of these letters may be read as a delightful chronicle of the adventures of a young American - Peirce was thirty years old at the time - visiting a string of widely different European countries: England, Germany, Austria, Turkey, Greece, Italy, Spain, France, Switzerland.

Our research focused primarily on the aspects of creativity and scientific cooperation. We were particularly interested in Peirce's aesthetic evaluations expressed in the letters, and in his effective collaboration with some of the most prominent European scientists of his time.

8 In the first phase of the project, the focus of our attention concerned the 17 surviving letters of Peirce's first visit to Europe. The letters, which were written by hand, also included skillful drawings. Because they were evidently not intended to be typed out or printed, we decided to reproduce the manuscript of the letters on the webpage of the project, as they were taken from the microfilms bought from the Harvard Photographic Service (which do not include the family correspondence) or from the photocopies available in the Peirce Edition Project. ${ }^{2}$ Peirce's handwriting, which is in itself very revealing, is usually very clear, and it provides a better and deeper picture of his personality, deeper than what typed transcriptions can offer.

In more detail, the project - over the period from December 2007 until August 2009 - has included the following tasks:

a) A careful transcription of the original English text of the 17 letters, minus the deletions, corrections, misspellings, etc., since the reader has the copy of the manuscript at hand. In this task, we have gratefully made use of Max Fisch's transcriptions of most of theletters, which have been made available at the Peirce Edition Project.

b) A faithful translation into Spanish of each text with frequent annotations in which the meaning of obscure passages is (almost always) clarified. These notes provide complementary information that substantially enriches the reading of Peirce's letters.

c) The publication of the translation of the letters on the web site of the project. Use was made of a good number of links - both in the text of the letters and in the notes - to illustrations, photographs, sources, etc. These links refer the reader to other pages of our web site as well as to external resources available on the internet.

Our overall aim is to give a global description of Peirce's European trips (in the first phase of our project, only the first trip of 1870-71), with an emphasis on what Peirce learned from Europe and on the way in which these trips changed his mind, particularly in respect of creativity and scientific cooperation. Moreover, we like to show, as a byproduct of our research, how internet may be used - and advantageously so, when compared to traditionally printed volumes - to publish this type of handwritten documents, by making 
them available to a wider community of scholars. The method may significantly contribute to the achievement of a greater degree of accuracy in transcriptions, translations and annotations of the texts. It moreover illustrates how the web can further the Peircean spirit of cooperation between scholars. ${ }^{3}$

\section{C. S. Peirce's First Visit to Europe: General Description and Biographical Data}

11 Charles S. Peirce traveled to Europe on five different occasions. The five trips occurred between the years 1870 and 1883, all of them "in the service of the Coast and Geodetic Survey, at that time the chief scientific agency of the United States. Peirce was in the first place a scientist, and his career was in the service of that agency. The years of Peirce's five European sojourns were: (1) 1870-71; (2) 1875-76; (3) 1877 ; (4) 1880 ; and (5) 1883 . The five sojourns together added up to nearly three of those thirteen years" (Fisch 1981b: 13). These trips made it possible for Peirce to get acquainted with European scientists and to further his international reputation as a researcher. In 1875 Peirce took part in the meeting in Paris of the Special Committee on the Pendulum of the International Geodetic Association, and in 1877, he was invited to the general conference of the Association held in Stuttgart. "Peirce attended the conference as accredited representative of the United States Coast and Geodetic Survey. That was the first formal representation of an American scientific agency in the sessions of an international scientific association" (Fisch 1981b: 15). In 1877, he was elected a member of the National Academy of Sciences.

The first trip to Europe, the examination of which is at present at the core of our project, extended from the 18th of June of 1870 to the 7th of March of 1871, all in all almost nine months. When leaving, Peirce was a young man of thirty years, with "high hopes," as he writes to his mother in his brief goodbye letter from Sandy Hook, New York, on the 18th of June. Young though he was, he had already been working successfully as a scientist since 1861. After finishing his studies at the Lawrence Scientific School at Harvard, he had started working as an aide to his father, Benjamin, for the U.S. Coast Survey. He also had taught two series of lectures at Harvard on the logic of science (the Harvard Lectures of 1865 and the Lowell Lectures of 1866), followed by a second series in which he lectured on the British logicians (Harvard, 1869). Moreover, he had been elected to be a member of the American Academy of Arts and Sciences (1867) and in 1869 he had been appointed as an assistant at the Harvard Observatory.

The main goal of Peirce's first trip to Europe was to identify possible locations suitable for establishing observatories in order to study the total solar eclipse that was to take place at noon of December 22nd, 1870 over the Mediterranean Sea. Moreover, his father Benjamin Peirce wanted to introduce his son to several European scientists. On June 18th, Peirce sailed for London in the company of his brother Jem, on the steamer S.S. Deutschland. The brothers separated in London, and Charles crossed to the continent. In the fall, Charles would be joined by his father, Benjamin, his wife Zina and the rest of the team of observers in charge of the observation of the solar eclipse.

Already in 1869, Charles S. Peirce had been a member of one of the teams in Kentucky that studied the total eclipse of the sun of August 7th of that year. The observation of the solar corona and its protuberances through telescopes, and the detection of helium by use of the spectroscope, led the American astronomers to formulate new theories 
regarding the composition of the sun that were received with a certain skepticism by European astronomers. The eclipse of 1870 provided the perfect opportunity to test those theories. Apparently, this eclipse made a deep impression on Peirce. Thus, he writes twenty five years later, in 1894:

of all the phenomena of nature, a total solar eclipse is incomparably the most sublime. The greatest ocean storm is as nothing to it; and as for an annular eclipse, however close it may come to totality, it approaches a complete eclipse not half so near as a hurdy-gurdy a cathedral organ. Few people who do not make journeys on purpose ever see a total eclipse. (CN 2.59, 1894)

Charles Peirce's itinerary led him from London, Berlin Dresden, Prague, Vienna, Pest, the Danube river, Varna (Bulgaria), the Black Sea, and, finally, Constantinople. From Constantinople Peirce traced the path of totality, that is to say, the path of the locations where the total eclipse would be visible, scouting for the most suitable locations of scientific observation. Thus, he pointed out such locations in Greece, Italy, and Spain, and thereby contributed to the success of the scientific expedition under the command of his father Benjamin. But, on the way, he also visited Amy Fay, his sister-in-law, in Berlin, who accompanied him during a delightful visit to Dresden. In Vienna he was kindly received by Edmund Weiss and Karl L. Littrow, director of the Observatory, and in Constantinople he enjoyed the guidance of the British orientalist Edward H. Palmer and his friend Charles Drake. All in all, Peirce traveled through the part of Europe that since July of 1870 had been involved in the Franco-Prussian War. In the end, he joined the team that observed the eclipse in the vicinity of Catania (in Sicily).

This journey constituted a really important experience for the young Charles Peirce, who was visiting Europe for first time. His letters are full of accounts of the impressions that the various places made upon him. For instance, he obviously enjoyed London, but not Berlin, where he complains in several letters of the awful smell (letters of June 30th, August 11th and September 4th). He describes Pest as "a rather pleasant place to stay" (letter of August 25th) and he writes that Constantinople is "by all odds the most beautiful \& fascinating place I have been in yet" (letter of September 2nd). Greece captivates him, but of Thessaly he writes that "on the whole I don't think Thessaly is very nice" (letter of September 15th). In a letter to his mother written in Chambéry in the Savoy region of France, Peirce enumerates the eighteen very different languages he heard spoken during his journey. On another occasion, he expresses his amazement at the large number of languages in which the newspapers of Constantinople are published (letter of September 2nd) or again, at the astonishing polygloth fluency of a lady he meets in the train (August 28th), which leads him to explain that even his fluency in French is inadequate (letter of August 28th).

The letters also show the human side of Peirce, like when he worries about getting robbed or ill, or when he is subject to his mood swings and sentiments. As a cosmopolitan traveler, Peirce writes pages and pages with comments about the climate and the weather, the dirt of the cities and places where he stays, about wines and food, prices and bargaining, clothes, means of transportation, and, in sum, about the customs and curiosities of the many places he is visiting. There are days where he feels on top of things, and there are days where he feels wretchedly homesick. Thus, on the 15th of September, he confesses to his mother in a letter written from Messina, Sicily, that "I begin now to feel the shortness of my time acutely at the same time that I am often quite homesick \& long to be home." A few days before, on the 2nd of September, he writes to his mother: "Considering how much pleasure I have had, I ought to be willing to put up 
with a fortnight pain," while on the 16th of November he writes, again to his mother: "This traveling about alone is good to teach a man the gift of silence. You won't find me such a rattle pate when I return."

18 Clearly, Peirce feels himself confronted by a world entirely different from the one he was used to. In a letter written from Constantinople and addressed to his wife (on August 28th 1870), he comments "If you could see what another world this is, you would wonder."

\section{Results of the Project}

\section{III. a) The Notion of Science and of Scientific Community}

19 From a scientific point of view the expedition of the U. S. Coast Survey in which Charles Peirce took part was a real success. It was very useful in its reinforcement of the observations done during the previous year with regard to the solar eclipse in Kentucky, in the sense that the effects observed in the solar corona and the protuberances confirmed the new theories of the American astronomers. "On the whole, the American observations and inferences of the preceding year were vindicated. This was Peirce's first experience of large-scale international scientific cooperation" (Fisch 1981b: 14). The observation of the eclipse, which occurred in a joint effort by American and European astronomers of several countries, was a genuine international experience. The "Reports of observations upon the total solar eclipse of December, 22, 1870" was published as Appendix $\mathrm{n}^{\mathrm{o}} 16$ of the Annual Report of the Superintendent of the Coast Survey of 1870. It makes for really worthwhile reading, especially so when it comes to the brilliant report written by Peirce's wife, including her drawing.

During the years preceding his first European trip, Charles Peirce had developed, under the supervision of his father, an extensive philosophical study, first on Kant and the categories, and later on logic, and particularly on the theories of the British logicians. Furthermore, between 1868 and 1869, Peirce had already published three of his most important texts, also known as to the "Cognition Series," in the Journal of Speculative Philosophy: "Questions Concerning Certain Faculties Claimed for Man," "Some Consequences of Four Incapacities" and "Grounds of Validity of the Laws of Logic."

Given his lectures on the British logicians, Peirce naturally wanted to get acquainted in London with some of the most outstanding logicians of his time. We know that on the 11th of July, he sent to Augustus De Morgan a letter of introduction from his father, together with a copy of his father's paper, "Linear Associative Algebra" and a copy of his own article "Description of a Notation for the Logic of Relatives, Resulting from an Amplification of the Conceptions of Boole's Calculus of Logic," which has been claimed to be "one of the most important works in the history of modern logic [for its being] the first attempt to expand Boole's algebra of logic to include the logic of relations." (Merrill: 1984, W 2, xlii). Though De Morgan was seriously ill, he did receive Peirce. We also know that Peirce presented a copy of his article to Stanley Jevons and that the latter replied to Peirce, because Peirce in turn replied to Jevons's reply in a letter from Pest on the 25th of August. Given the fact that De Morgan and Jevons were key contributors to the development of exact logic, one can better appreciate the importance of Peirce's paper. For indeed, his paper was discussed as part of the broader discussion concerning Boole's Laws of Thought at the Liverpool meeting of the British Association for the Advancement 
of Science in September (Fisch, 1984, W 2, xxxiii). Peirce's paper was published in the Memoirs of the American Academy of Arts and Sciences (vol. 9, 1870, 317-8).

For Peirce, this first trip through Europe was the right occasion to establish his prestige as a scientist and to get in contact with several scholars, most evidently astronomers (Lockyer, Littrow, Plantamour, Weiss, etc.), but also with important representatives of other fields such as mathematics and logic (Clifford, De Morgan, Jevons, etc.). It was his ambition to take an active part in the community of researchers. But this ambition was less of a personal nature than that it was the expression of his conviction that the search for truth was necessarily a collective project. And even though the letters studied so far, which for the most part were addressed to members of his family and therefore did not refer to his notion of science, they exhibit some traces of his scientific activities during the trip. Thus, Peirce writes to his father about the purchase of scientific instruments (letter of July 12th), about the suitability of various places - for instance, Kavala in Greece - for the observation of the eclipse (letter of September 5th), and about his visit to the British Museum and his contact with De Morgan (letter of July 12th).

Although there is no doubt that the study of the letters written during Peirce's later overseas travels may yield a more complete picture of the way in which his acquaintance with the professional practice in Europe influenced his notion of science, the letters studied so far show that his active participation in a scientific project that required an effort by an international scientific community reflected or reinforced his belief that science is a profoundly creative activity aiming at the discovery of truth, and that such activity is marked by two irreducible properties: it must be communitarian, and it must be fallible.

One finds a good example of a reference to the communal nature of science in Peirce's letter from August 25th to Stanley Jevons, in which he establishes an interesting dialogue with the British logician about his conception of logic, in which one finds one of his earliest formulations of his distinction between different kinds of signs: "icons," "indexes," and "symbols." Peirce ends his letter by saying: "I trust you will feel enough interest in this discussion to continue it," thereby expressing that the dialogue is at least as important as his own view of the matter.

Later, Peirce would characterize the scientist as someone whose life is animated by the desire to find out the truth (MS 615, p. 14, 1908), by "an impulse to penetrate into the reason of things" (CP 1.44, c.1896), and he would state, as he always did, that the scientific method is the only correct method to develop that search. For Peirce, science is a particular application of a method that enables us to deal creatively with reality. The construction of hypotheses constitutes the heart of that method. What constitutes science "is not so much correct conclusions, as it is a correct method. But the method of science is itself a scientific result. It did not spring out of the brain of a beginner: it was a historic attainment and a scientific achievement" (CP 6.428, 1893). Contrary to the popular image of science as something finished and based on a dead and rigid methodology, science is for Peirce "a living historic entity" (CP 1.44, c.1896), "a living and growing body of truth" ( $C P$ 6.428, 1893), something that is alive and enables our thought to continuously grow towards the truth.

Peirce's notion of science as a living activity, carried on throughout centuries by different persons of different ages, derives from his own intense involvement in scientific practice. For Peirce this activity always takes place within the one and only community of research 
which itself generates the scientific method, and extends beyond the past and the present, into the future. Already in 1868 , Peirce had written that:

[t] he real, then, is that which, sooner or later, information and reasoning would finally result in, and which is therefore independent of the vagaries of me and you. Thus, the very origin of the conception of reality shows that this conception essentially involves the notion of a COMMUNITY, without definite limits, and capable of a definite increase of knowledge. And so those two series of cognition the real and the unreal - consist of those which, at a time sufficiently future, the community will always continue to re-affirm; and of those which, under the same conditions, will ever after be denied. (CP 5.311, 1868)

The members of this community try to explain and make publicly accessible the results they have achieved, as well as the method by which they have arrived to the opinions they hold. The scientist must take into consideration the opinions of the other members of the community, for only in this way is it possible for the search of truth to progress, in the hope that it will be achieved, independently from any individual member of the scientific community. In 1901, Peirce writes:

The scientific world is like a colony of insects, in that the individual strives to produce that which he himself cannot hope to enjoy. One generation collects premises in order that a distant generation may discover what they mean. When a problem comes before the scientific world, a hundred men immediately set all their energies to work upon it. One contributes this, another that. Another company, standing upon the shoulders of the first, strikes a little higher, until at last the parapet is attained. (CP 7.87, 1901)

This typically Peircean view appears in some way in a casual remark he makes in a letter written from Pest to his brother Jem on the 25th of August of 1870. Apparently Jem had been trying to convince his brother not to travel to Greece because of the danger of catching the yellow fever. To this, Peirce replies:

I think myself that to go into Greece is not entirely safe but I shall reduce my stay there to a minimum. I cannot well avoid going there \& if as is not after all probable I get the fever why I shall not for my own sake care at all \& I should be no great loss socially. You will have done what you could to keep me away, but it is quite absurd to be made unhappy by the regular \& normal course of human events. If I should never come back I trust my friends will remember that the less they care for it the more they conform to my ideas.

Clearly, Peirce is convinced that in the search for truth, the contribution of an individual is relatively unimportant, because the achievement of truth will in the long run be the result of the work of the community of scientists over many generations.

In this communal effort, individual scientists continually stimulate and criticize one another, for their work must to be open to the judgment of others. The scientist needs the approval of the community. However, as Peirce points out in 1870, the same year in which he embarks upon his first European journey, that 'community' is not synonymous with 'majority': "Then by the truth concerning a thing we do not mean how any man is affected by a thing. Nor how a majority is affected. But how a man would be affected after sufficient experience, discussion, and reasoning." (W 2.440, 1870). It is not the community as such, but the experience, discussion and reasoning that takes place within the community that paves the way for the real advancement of science towards the achievement of truth.

31 This stipulation leads us to the consideration of the second condition which Peirce, from the very beginning, thinks is of the greatest importance to scientific thought. Every 
scientific proposition must be fallible. One must not mistake "whatever I am clearly convinced of" with what is true (cf. CP 5.265, 1868). Fallibilism does not mean that there is no hope to ever obtain sound knowledge or that it is not possible to reach the truth in the long run. The methods of science are successful, but in the short term they may yield both errors and successes. We always must attempt to overcome doubt (CP 7.109, c.1910), we must always trust that a question "has one answer decidedly right, whatever people might think about it" (CP 2.135, c.1902), and that error has a positive effect in bringing out the truth. Peirce writes: "The essence of truth lies in its resistance to being ignored." ( CP 2.139, c.1902). Far from being a pessimistic view, Peirce's fallibilism stems from the combination of his unshakeable belief in the possibility of achieving truth, with his conviction that progress must always remain open-ended. Thus, doubt, a living and real doubt, as opposed to a doubt on paper, together with error, make for the twin engine that drives scientific research. The scientist - Peirce writes - "stands ready to abandon one or all [of his or her beliefs] as soon as experience opposes them." (CP 1.635, 1898)

We will end this section with a suggestive text that sums up all we have said so far about Peirce's conception of science and the scientific community:

But if I am asked to what the wonderful success of modern science is due, I shall suggest that to gain the secret of that, it is necessary to consider science as living, and therefore not as knowledge already acquired but as the concrete life of the men who are working to find out the truth. Given a body of men devoting the sum of their energies to refuting their present errors, doing away with their present ignorance, and that not so much for themselves as for future generations, and all other requisites for the ascertainment of truth are insured by that one. (CP 7.50, $n$. d)

\section{III. b) Aesthetics and Artistic Creativity}

Although Peirce affirms not being well acquainted with aesthetics (CP 1.191, 1903), he always was interested in it. It is unclear why he did not write more on this field: perhaps due to the scientistic atmosphere in which all his life turned out. In spite of the fact that Peirce did not developed widely the point, aesthetics is located in a very important place in all the architecture of his conception, when in the turn of the century he develops his idea of aesthetics as the foundation of the other normative sciences. Aesthetics as the first of normative sciences has for Peirce a special quality of firstness. "Aesthetics considers those things whose ends are to embody qualities of feeling" $(C P 5.129,1903)$. Its task is to determine which is the summum bonum that has to serve as an end to the other two normative sciences; to tell "what it is that is admirable without any reason for being admirable beyond its inherent character" $(C P 1.612,1903)$.

Thus, while for the scientist the main thing is thought and nothing seems great but reason, the artist has to be busy with his or her feelings. Men who create art, Peirce writes, are those "for whom the chief thing is the qualities of feelings," differing from the practical men, who carry on the business of the world, and the scientists (CP 1.43, c.1896).

Thus, for Peirce, art is related to "qualities of feelings," to whatever is or exists independently of whatever other thing, without any element of being relative to, or of mediation (cf. CP 6.32, 1891). Beauty is for Peirce the only thing that we admire in itself and not in respect of something else. But, this does not answer the question how beauty is to be recognized? What works of art may be considered beautiful? Here, the letters that were examined in our project provide an excellent source of insight into Peirce's 
conception of beauty. The specific experiences to which he refers in those letters, his comments on the works of art that he saw in Europe, and his personal way of observing them give us a glimpse of the conception of art that he would develop in later years.

In his letters Peirce often dwells on his admiration for beauty, whether in nature or in artifacts, and he enjoys sharing with his reader the feelings which the contemplation of beautiful things elicits in him. The core of his aesthetic experience is often related to this admiration, whether it be for the greatness of nature or for manmade things. Some works of art struck him as particularly beautiful. Thus, he felt great admiration for the Tiergarten in Berlin which he describes as "enchanting," for Potsdam and Sans Souci, for the mosque of Suleiman in Constantinople, for a bust of Faustina in Catania "which I couldn't tire of looking at" (letter of September 22nd), and for the basilica of Santa Maria Maggiore in Rome, which he mentions in a letter of October 14th, addressed to his mother and where he writes that he "was greatly struck by this church."

But he also marvels at the Bohemian mountains, the Hungarian hills, the Carpathian Mountains, the Danube-of which he writes, while sailing down the river towards the Black Sea that "I believe no river in the world is so fine as this part of the Danube" (letter of August 28th), and the Bosphorus. He expresses his sense of awe as he experienced the famous view of Constantinople when approached from the sea, and he marvels at the sight of Ossa and again at the appearance of Pelion in Greece.

Whenever Peirce explains why he likes or dislikes something, he always does so in function of its capacity to convey something to the beholder. Thus, in his letter written from Berlin on July 30th of 1870 , he remarks that the sculptures and architecture of the city fail to produce any real effect on the visitor:

The architecture and sculpture have a very artificial and made up look, generally imitations of classic style and fail altogether of any real effect even when you must acknowledge them to be fine. The finest thing is the Victory over the Brandenburg Thor [sic] and that has the effect of a small bronze. The artist has taken no advantage at the large size to produce any particular effect of greatness or sublimity.

Similarly, when he refers to St. Peter's cathedral in Rome, he remarks that "there is an absence of true belief about St. Peter's. Its got up. [...] It is the enormous size \& perfect proportions of St. Peter's that impresses one. Beyond that there is nothing great about it" (letter of October 14th). He applies the same criterion of the effect of a work of art upon the beholder when he speaks of literature. In a couple of letters Peirce refers to his reading of Balzac. On the 4 th of September he writes that he enjoyed reading the author's Honorine and he expresses his admiration for Balzac's grasp of human nature. In a letter written on the 14th of October, he reiterates his admiration for the French author, praising Balzac's power of description, but then he adds that the author disappoints him to the extent that he fails "to interest the reader very much in any of his characters; it is all a mere study without sympathy." This capacity, or lack thereof, of touching the beholder of a work of art is for Peirce the touchstone whereby good works of art can be distinguished from lesser creations. Another example of this may be found in his comment regarding the poverty-in his estimation-of ideas in Muslim architectonic style when compared with the Gothic style: "Saint Sophia is fine but the style of it is altogether below the Gothic \& I thought the Saracenic a style of architecture rather poor in ideas" (letter of 4th September). 
Sometimes, the outcome of his evaluations may be surprising. Thus, he was totally smitten by the expressive force of Antonio Canova's sculptures, whereas his evaluation of Michelangelo is devastating. In the letter of October 16th from Rome, he writes:

There are two monuments by Canova here. One of them very striking. I greatly admire Canova. My opinions on the subject of painting \& sculpture I am generally hold very timidly but not this one. I think Canova great - very, very great. I was first struck - indeed quite overwhelmed - by his Theseus Killing the Minataur in Vienna. Then I was greatly pleased with his Pauline Borghese \& now this monument of Clement XIV I think has great power.

41 But when it comes to the sculptures of Michelangelo, he thinks they are "horrid and misproportioned":

I then went into the monastery adjacent to this church \& saw a monument by Michael Angelo. But to appreciate Michael Angelo's statues requires more knowledge of the history of art than I have got. They seem to me horrid misshapen \& misproportioned things.

One month later, on the 16th of November, in a letter written in Chambery and addressed to his mother, Peirce complains of the absence of motivation and convictions that characterizes his era. By this he means that there is nothing modern artists want to express to their public. In other words, he bemoans the formalism of contemporary artists.

Canova's statues \& some few pieces of modern art make one feel that all this age needs in order quite to eclipse all others in art is the Motive - but that you see is totally wanting. Art is a mere plaything or luxury now. What are our artists! Are they the representative men of our age at all or do they even at all comprehend it? The difficulty is our age has no belief; it doesn't half believe in itself even. As long as that is so it yet asks for critics \& scientific men \& not artists.

This complaint too foreshadows Peirce's later conviction that art consists precisely in expressing something and in producing some effect in those who contemplate the work of art; art must represent a quality of feeling, which as such is purely possible, so as to make that possible quality of feeling actually felt in the interaction between the work of art and the beholder. The true creative power of the artist is to capture what cannot be grasped, and making it reasonable. The artist grasps and expresses what otherwise would remain hidden, unrealized, and merely a possible. In 1903, Peirce writes:
It seems to me that while in esthetic enjoyment we attend to the totality of Feeling
- and especially to the total resultant Quality of Feeling presented in the work of art we are contemplating - yet it is a sort of intellectual sympathy, a sense that here is a Feeling that one can comprehend, a reasonable Feeling. I do not succeed in saying exactly what it is, but it is a consciousness belonging to the category of Representation, though representing something in the Category of Quality of Feeling. (CP 5.113, 1903)

For Peirce art has precisely this capacity of grasping or fixing these qualities of feeling and of exhibiting them so they can be contemplated. The artist takes as a source of his work the matter found in his experience of the world, the sentiments, the impressions that his life, historical contexts or social occasions cause in him. But, contrary to other people, the artist is able to express this matter in a peculiar way that calms the initial anxiety. For Peirce, the artist is someone who in a surprising and almost magical way grasps feelings of qualities that by their very nature are isolated and hidden, and who then succeeds in making them in some sense reasonable, understandable. 
rary to most people, who consider aesthetics as something completely opposite to the rational, Peirce sees art as a form of thirdness, or reasonableness in art. According to this conception, the artistic phenomenon requires the combination of three elements. To begin with, there is firstness, the quality of feeling that the artist perceives without even being conscious of it; then there is the reaction to this firstness, as it appears in writing, in painting or in another form of creation, and thus giving rise to something that exists in the actual world, a work of art in a world of facts, which in Peircean terms is of the order of secondness; and finally there is representation (in Peircean terms, of the order of thirdness), which is the capacity to grasp ineffable firstness, and translating it in something communicable by means of sentences, lines, or a succession of musical sounds. Together, the three categories are at the heart of the artistic phenomenon.

heters Peirce refers to the amazing multitude of feelings, sensations and impressions to which he is exposed and which he wants to hold on to. In his letter of August 28th, he writes: "I thought today I would rest \& write letters. I have seen so much that unless I go over it in my mind it will escape me. I feel I have now forgotten ever so many things which interested me greatly." The sheer wealth of such feelings may explain why Peirce's letters to his family sometimes feel more like a journal than of letters. In his letter of September 4th, written while sailing towards Greece and addressed to his wife, he literally writes, "for the next few days I shall be able to keep a regular journal," and two days before, in a letter from Constantinople, he regrets not having more time to describe everything that appears around him: "There is such a flood of complete novelty before my eyes everywhere that I have no time to get used to it at all even enough to describe it. What shall I begin with?"

At the same time, his great desire to give an account of the strong impressions raining down upon him is matched by his awareness of how difficult it is to do justice to them, simply because their character of firstness resists all attempts to put them into words or even drawings. This is particularly so for the beauty of nature which no art can express. In his letter of September 22nd, addressed to his wife, he points out that "[i]t is difficult to give a notion of the character of a country so unlike what you have seen," and then goes on to describe the sunrise as seen from the Greek theater of Taormina; but then he surrenders and writes:

But how can I give you any sort of notion of the enchanting, enchanting view? I was standing in a very lofty promontory in the pure undeceptive light of morning looking down upon the sea. Just below me, 50 feet or so, was this ancient theatre. In ruins but enough left to show readily how it used to be with its beautiful columns, circles \& arches, quite enough to be very beautiful still. Enough to make you think the people who selected this enchanting site for it hadn't been gone so very long. I was not at the summit of the promontory, though very high. High above me was an awful rocky head, the ancient acropolis, crowned with a formidable looking fortress. For many miles along the shores stretched such hills as I had seen the day before with sunny valleys beneath them \& the sea rolled in onto the beach. I could see many villages both in the valleys \& on the hills - nearest of course the curious little town of Taormina \& much verdure. Across the sea on one side the shores of Calabria were very prominent \& in the opposite direction over the land rose Etna majestic \& awful. It is to see such things as this that it is worthwhile to come abroad, things which no art can reproduce.

But, while Peirce appears to recognize the limitations of art to the degree that it can not do justice to nature, Peirce is even more aware of his own limitations in conveying his feelings and admiration for the works of art he sees, and more specifically his limitations

European Journal of Pragmatism and American Philosophy, l-1/2 | 2009 
in the reproduction of what he has seen. For instance, in a letter of 28th of August, he writes that he is seeing things which his imagination is incapable of drawing and his memory is unable to remember. For instance, he tried to reproduce the bust of the empress Faustina that he had enjoyed so much in Catania, but he did not succeed in doing so: "Here was another thing not to be reproduced. Memory itself cannot do justice to this beautiful work" (letter of September 22nd). In the same letter he adds that his drawings of a Venus that had struck him as being so beautiful that it in some sense it surpassed even Titian's Venus, were incapable of expressing the essence of that work of art, and were therefore no more than "positive libels."

All in all, Peirce's European experience may well have been an important source of Peirce's later view of the artist as a person who is able to give a form to what cannot be expressed, to soothe the anxiety, and to express the admiration which something inspires in him. Peirce's attempt, many years later, at writing a literary tale, the only surviving fiction by Peirce, may be seen as his attempt at being an artist. In the tale he tries to express the impressions and feelings that he had experienced during his journey through Greece. This tale, entitled Topographical Sketches in Thessaly, with Fictional Embroideries, may be considered as a practical experiment of Peirce's notion of art. Art makes it possible for human experience, in all its variety and its resistance to comprehension, to become reasonable to the degree that, by providing a point of view from which mere feelings receive meaning (in Peircean terms, 'thirdness'). Thus, metaphorically Art may be said to colonize and to tame feelings. Beauty arises when harmony and equilibrium come into the picture, when a perfect adjustment is achieved between the feelings expressed and the form in which they are expressed, so that a "reasonable embodiment" occurs. In this way, in order for a work of art to be beautiful, it should move us or it should provoke in us some type of emotion, of feeling, and at the same time move us to some reflection. These reactions may have been what Peirce hoped for when he read his tale about Greece to an audience in the Century Club of New York (MS L387: letter to Francis C. Russell, 4th of May, 1892), and then again in the homes of one or two friends. And he may have been successful in obtaining this effect, as is testified by a letter in which John Fiske, who attended one of those sessions, wrote to Peirce: "I was wildly interested in it and believed every word while you were reading. It was as real as them 'ere grapes of Zeuxis which the birds pecked at"' (MS L146, 14th of June, 1893). Certainly, Peirce would have endorsed Picasso's words: "A work of art must not be something that leaves a man unmoved, something he passes by with a casual glance. It has to make him react, feel strongly, start creating too, if only in his imagination. He must be jerked out of his torpor." (Huffington 1989: 291).

\section{III. c) Peirce's European Correspondents}

51 Part of our project, entitled "Peirce's European Correspondence: Artistic Creativity and Scientific Cooperation," was the creation, over the past two years, of a number of webpages featuring, respectively, eight of the main European correspondents of Peirce. These pages - some of which are still being constructed- together with the correspondence included in those pages between Peirce and some of the most prominent figures of the contemporary scientific and cultural European scene, offer, albeit in an often fragmentary way, a good picture of Peirce's belief in the social nature of science and creativity, and in the need for integration in the international community of scholars, the 
"unseen brotherhood of science," to use the words of his father Benjamin in the letter of the 17th of June in which he introduces his son Charles to Augustus de Morgan.

In a manuscript from around 1907, Peirce openly acknowledges the importance of his European journeys, because they enabled him to obtain a direct acquaintance with the most relevant opinions of his time. The following passage, which we have chosen as the motto of our project, says it all in a nutshell:

Philosophy is a study which needs a very protracted concentrated study before one so much as begins to be at all expert in the handling of it, if one is to be precise, systematic, and scientific. I gave ten years to it before I ventured to offer half a dozen brief contributions of my own. Three years later, when I had produced something more elaborated, I went abroad and in England, Germany, Italy, Spain, learned from their own mouths what certain students at once of science and of philosophy were turning in their minds. (Letter to The Sun, MS 325: 4, c.1907)

First and foremost in the list of Peirce's European correspondents were the two British logicians, Augustus de Morgan and Stanley Jevons. In his work, Peirce often quotes De Morgan (1806-1871), the co-founder and first president of the London Mathematical Society. The admiration he always felt for the man, who died within ten days after Peirce had returned from Europe, finds its expression in the obituary of De Morgan, which Peirce wrote in The Nation on April 13th, 1871:

As a writer and a teacher, he was one of the clearest minds that ever gave instruction, while his genial and hearty manners in private and in the school-room strongly attached to him all who came in contact with him. He was a man of full habit, much given to snuff-taking; and those who have seen him at the blackboard, mingling snuff and chalk in equal proportions, will not soon forget the singular appearance he often presented. (CN 1.42)

We see another aspect of this admiration in a text of 1898 , in which Peirce recalls his meeting with De Morgan in London in 1870 during his first trip to Europe. During that meeting, Peirce had apparently pointed out the revolutionary importance of Boolean algebra. Here is how he describes De Morgan's reaction:

[...] the immense superiority of the Boolian method was apparent enough, and I shall never forget all there was of manliness and pathos in De Morgan's face when I pointed it out to him in 1870. I wondered whether when I was in my last days some young man would come and point out to me how much of my work must be superseded, and whether I should be able to take it with the same genuine candor. (CP 4.4)

55 The importance for Peirce of that meeting appears in another letter (December 5th 1908) from Peirce, this time to the British logician Philip Jourdain (1879-1919), in which he makes reference to that meeting:

As far as my recollection goes, I was in London in 1870 for some months and called on De Morgan and carried him my paper and he then presented me with his; and I should say from memory unchecked, that almost all my acquaintance with De Morgan's system was derived from that and his Syllabus which he gave me the same day. (NEM 3.383)

56 Stanley Jevons (1835-1882) is remembered nowadays as one of the main characters of the "Marginalist Revolution" in the political economy of the 19th century and as one of the champions of the mathematical approach to economy. Besides being the author of other interesting developments in logic (for instance, his defense of the inclusive interpretation of the disjunction), Jevons invented a mechanical procedure to perform inferences. Peirce's references to Jevons are numerous and show a sound knowledge of his work. But 
they also show the strong differences of opinions between the two men which sometimes forced Peirce to be very critical of an author he nevertheless sincerely admired. That the admiration was reciprocal may be seen from the few occasions when Jevons lavishes praise on Peirce. For instance, he writes that " $[t]$ he most elaborate recent contributions to mathematico-logical science, at least in the English language, are the memoirs of Prof. C. S. Peirce, the distinguished mathematician, now of the Johns Hopkins University, Baltimore" (Jevons 1881).

Our study of the European scientists who communicated with Charles Peirce includes also Wilhelm M. Wundt (1832-1920) and Hermann L. F. von Helmholtz (1821-94). Helmholtz decisively influenced the course of the modern development of a number of disciplines, such as physiology, psychology, optics, acoustics and electrodynamics. When he visited the United States in 1893, he met with a number of American scientists. Peirce was one of them. He very often mentions Helmholtz in the context of his reference to the first law of thermodynamics, which was undeniably one of the most outstanding scientific discoveries of that time. It was again Peirce who wrote the obituary of Helmholtz for The Nation, in which he displays his great appreciation of the German scientist, "the acknowledged and worshipped head of the scientific guild." Peirce added that "a reward was due from organized humanity to the man who had thus lifted man's mind to a higher vantage ground":

In every case he so conducted himself as to bespeak an imperious desire to find out the truth and to publish it; and every approach to personality was avoided or flung away from him as a pestilential infection. The world owes much to the intellectual clearness and integrity of Hermann Helmholtz, M.D.

We also paid particular attention to the only Spaniard on the list of Peirce's correspondents, the mathematician Ventura de los Reyes y Prósper (1863-1922), who remarks that "Peirce knows how to find exceedingly curious connections between things that at first glance seem not to exist" (Reyes, 1892: 171).

When it comes to the discipline of linguistics and semiotics, Peirce's correspondence with Victoria Lady Welby (1837-1912) was of special importance, both for Peirce himself and for the reception of Peirce's thought in Europe. Lady Welby was a distinguished British aristocrat who functioned as a mediator of ideas between a number of British, Continental and American intellectuals of the last decades of the nineteenth, and the first decade of the twentieth century. She denounced above all the "linguistic anarchy" (Macdonald 1912: 155) that governed philosophical discussions, and in some way she anticipated the therapeutic approach to the use of language that would later be attributed to the later Wittgenstein (Deledalle 1990: 134). Peirce's correspondence with Lady Welby started in 1903 and lasted until 1912 when Welby died. The correspondence actually started after the publication of her book What is Meaning? Lady Welby contacted Peirce, after having read several of his entries written for Baldwin's Dictionary of Philosophy and Psychology (1902). But it seems that both already knew about one another several years before (Schmitz 1985: cxlviii). In fact, Welby already mentions Peirce in 1893. In her reply (letter from August 17th 1893) to a letter from Paul Carus, the editor of The Monist, in which the latter describes Peirce as "a very ingenious and personally highly interesting thinker, a genius of great power" (letter of August 2nd, 1893), she answers "I am very much amused at what you say about Mr. Peirce, whose ability is well-recognized here, especially on the side of Logic" (August 17th, 1893). In his review of What is Meaning? (CN 3.143-145, CP 8.171-175), Peirce points out that the valuable distinction which Welby 
makes between three orders of signification corresponds more or less with his own distinction between three kinds of interpretants.

Besides studying the above mentioned European correspondents, we also paid attention to the interesting figure of Edward H. Palmer (1840-82), a Cambridge professor of Arabic languages whom Peirce first met in Constantinople on the 2nd of September of 1870 and subsequently in England on several occasions. Peirce refers to him in several places and states that it was under the influence of Palmer that he began to study Arabic. Finally, we must mention our study of Peirce's correspondence with the Italian moral philosopher Mario Calderoni (1879-1914). In 1905, Peirce addressed a very important letter to Calderoni in which he explained his own notion of pragmatism and its link with scholastic realism. Thus, he writes: "[Pragmatism] is not a system of philosophy. It is only a method of thinking; and your correspondent, Giuliano il Sofista [the pseudonym of his opponent Giuseppe Prezzolini in Leonardo], is quite right in saying that it is not a new way of thinking."

\section{Conclusion}

61 Our project on "Peirce's European Correspondence: Artistic Creativity and Scientific Cooperation" may be said to have achieved its main goal with regard to the completion of the transcription, the translation into Spanish, the annotation and illustration, and the internet publication of the 17 letters written by Charles Peirce during his first European journey. To this must be added the construction of additional web pages featuring eight of his European correspondents. In the development of this project so far, we made two genuinely new discoveries: 1) Peirce's signature in the Reading Room of the British Museum on the 18th of July; and 2) Charles Drake's diary of 31 August of 1870 in which his visit of Constantinople in the company of "Mr. Peirce (an American)" is accurately described. Moreover, dozens of annotations and links in the letters provide a clearer image of the things and places which Peirce actually visited during his European trip.

Given the additional funds we expect to obtain, these positive results of our study of Peirce's first European trip pave the way for the other planned stages of the project, in which the later European visits and Peirce's later correspondence with other European scholars will be investigated. We are also considering the possibility of translating the letters and our annotations into other European languages.

Generally speaking, our investigation has shown that the importance of the letters written by Peirce during his first visit to Europe by far exceeds their anecdotal content. In fact, they may be said to have contributed in a significant way to Peirce's personal development as a scientist and as a philosopher. Moreover, the letters cast a light on the special combination of intelligence and sensitivity that is so characteristic of Peirce. Furthermore, one finds in the letters the seeds of several theories that he would develop in later years.

64 We also have tried to show the significance for Peirce of his participation in his first international scientific mission and of his first contact with the European community of scientists. More specifically, the experience may be said to have confirmed two of his most profound convictions regarding science: the conviction that science is a communal effort, and the paradoxical conviction that science, in order to be science, must be fallible. Similarly, we have seen the impact on Peirce of his contemplation of the many 
works of art he saw in a great variety of places of Europe, and how that experience decisively influenced his conception of art as the capacity of expressing qualities of feeling so as to make them reasonable.

Our project has helped us to better understand Peirce, as a scientist and as a philosopher, but moreover as somebody profoundly human and alive, always open to the full impact of the experiences and impressions to which he was subjected while traveling. The seeds of the feelings he experienced in Europe would have a lasting effect, so as to yield a harvest in which new ways of understanding science and art would be developed. Peirce's thought cannot be separated from his life, and his first European visit provides us with a better understanding of one of the greatest American thinkers of all times.

\section{BIBLIOGRAPHY}

BARRENA S., (2003), La creatividad en Charles S. Peirce: Abducción y razonabilidad, Doctoral diss., Universidad de Navarra, Spain.

Deledalle G., (1990), "Victoria Lady Welby and Charles S. Peirce: Meaning and Significaction," in Essays on Significs, A. Eschbach, editor, Amsterdam, Benjamins, 133-49.

FISCH M. H., (1981a), “Introductory Note,” in Th. A. Sebeok, The Play of Musement, Bloomington, Indiana University Press, 17-21.

FISCH M. H., (1981b), "Peirce as a Scientist, Mathematician, Historian, Logician, and Philosopher," in Proceedings of the C. S. Peirce Bicentennial International Congress, K. L. Ketner et al, editors, Lubbock, TX, Texas Tech Press, 13-34.

FISCH M. H., (1984), “The Decisive Year and Its Early Consequences,” in W 2, xxi- xxxvi.

FISCH M. H., (1986), Peirce, Semeiotic and Pragmatism, K. L. Ketner \& Ch. J. W. Kloesel editors, Bloomington, Indiana University Press.

huffington A. S., (1989), Picasso. Creator \& Destroyer, London, Pan Books.

JEVONS W. S., (1881), “Recent Mathematico-Logical Memoirs," Nature 23, 485-7, (24 of March).

MACDONALD W., (1912), "Lady Welby,” The Sociological Review, 5 (2), 152-6.

MERILL D. D., (1984), “The 1870 Logic of Relatives Memoir,” in W 2, xlii-xlviii.

MURPhey M. G., (1961), The Development of Peirce's Philosophy, Cambridge, MA, Harvard University Press.

NUBiola J. \& F. Zalamea, (2006), Peirce y el mundo hispánico. Lo que C. S. Peirce dijo sobre España y lo que el mundo hispánico ha dicho sobre Peirce, Pamplona, Ediciones Universidad de Navarra.

REYeS Y PRÓSPER V., (1892), “Charles Santiago Peirce y Oscar Howard Mitchell,” El Progreso Matemático II: 18 (15th of June), 170-73.

schmiтz W. (ed.), (1985), Significs and Lenguage: The Articulate Form of Our Expressive and Interpretive Resources by Victoria Lady Welby, Amsterdam, Benjamins. 
WEISS P., (1934), “Charles Sanders Peirce," in D. Malone (ed.), Dictionary of American Biography, New York, Scribner, vol. 14, 398-403.

\section{APPENDIXES}

\section{Sources of Peirce's Texts}

CN Peirce C. S., (1975-1979), Contributions to “The Nation," vols. 1-4, K. L. Ketner \& J. E. Cook, editors, Lubbock, Texas Tech Press.

CP Peirce C. S., (1931-1958), Collected Papers of Charles Sanders Peirce, vols. 1-8, C. Hartshorne, P. Weiss, \& A. W. Burks, editors, Cambridge, MA, Harvard University Press.

MS The Charles S. Peirce Papers, (1966). 32 microfilm reels of the manuscripts kept in the Houghton Library, Cambridge, MA, Harvard University Library, Photographic Service.

NEM Peirce C. S., (1976), The New Elements of Mathematics, vols. 1-4, C. Eisele, editor, The Hague, Mouton.

W Peirce C. S. (1982- ), Writings of Charles S. Peirce: A Chronological Edition, vols. 1-6. M. H. Fisch et al., editors, Bloomington, IN, Indiana University Press.

\section{NOTES}

1. Taking advantage of the on-line nature of this journal, we have introduced in the texts a lot of links to the more illustrative pages of our project. Most of the links go to pages in Spanish according to the target of our Group. We hope that in the future some of the more valuable documents may be translated to other European languages by a European Peirce Network.

2. Without the generous help of the Peirce Edition Project our project could not have been done. We are extremely grateful to Nathan Houser and André de Tienne for all the extensive support they have provided us.

3. In 2006, our project was presented to the Government of Navarra, which issued a positive evaluation. Unfortunately, budget limitations made it impossible for the government to provide the necessary funds. Fortunately, the Plan of Research of the University of Navarra approved the required funding for the first phase. In our web it is possible to check our applications to the Gobierno de Navarra and to the University of Navarra where the antecedents, methodology and goals of the project are described in detail (in Spanish). 